\title{
Cysteinyl Leukotrienes Mediate Histamine Hypersensitivity Ex Vivo by Increasing Histamine Receptor Numbers
}

\author{
Gwenda Pynaert, ${ }^{1,2}$ Johan Grooten, ${ }^{1}$ \\ Sander J. H. van Deventer, ${ }^{2}$ and Maikel P. Peppelenbosch ${ }^{1,2}$ \\ ${ }^{1}$ Department for Molecular Biology, Flanders Interuniversity Institute \\ for Biotechnology and University of Ghent, Ghent, Belgium \\ ${ }^{2}$ Laboratory for Experimental Internal Medicine, Academic Medical \\ Centre, Amsterdam, The Netherlands
}

Accepted September 7, 1999.

\begin{abstract}
Background: Hyperresponsiveness to histamine is a key feature of a variety of pathological conditions, including bronchial asthma, food allergy, colitis ulcerosa, and topical allergic disorders. Cells isolated from hyperresponsive individuals do not display exaggerated histamine responses ex vivo and thus the molecular mechanisms underlying histamine responsiveness remain obscure. Importantly, several in vivo observations implicate cysteinyl leukotrienes as possible mediators of increased histamine responses. We decided to investigate whether cysteinyl leukotrienes enhance the cellular reaction to histamine in cell types involved in pathological and immunological histamine hyperresponsiveness, as this might provide an in vitro system for studying histamine responsiveness and could shed light on the underlying molecular mechanisms.
\end{abstract}

\begin{abstract}
Materials and Methods: Histamine responsiveness was determined by measuring histamine-induced prostaglandin $E_{2}$ production. Scatchard analysis was performed to determine the number of histamine $\mathrm{H}_{1}$ receptors. Mouse macrophages, primary isolated human peripheral blood monocytes, and human umbilical smooth muscle cells were investigated before and after cysteinyl leukotriene stimulation.

Results: In all three cell types tested, cysteinyl leukotrienes instantaneously enhanced histamine-induced prostaglandin $\mathrm{E}_{2}$ production. This increase in prostaglandin $\mathrm{E}_{2}$ production coincided with the immediate and transient appearance of additional $\mathrm{H}_{1}$ receptors on the plasma membrane.

Conclusions: Cysteinyl leukotrienes prime histamine responses by recruiting additional histamine receptors in immunologically relevant cell types in vitro.
\end{abstract}

\section{Introduction}

Histamine, which is produced by decarboxylation of the amino acid L-histidine (1), is found in most tissues, mainly in the granules of mast cells, although numerous other cell types are capable of histamine synthesis as well (2).

Address correspondence and reprint requests to Dr. Maikel P. Peppelenbosch, Laboratory for Experimental Internal Medicine, G2-130 Academic Medical Centre, Meibergdreef 9, NL-1105 AZ Amsterdam, The Netherlands. Phone: 31 20-5665910; Fax: 31-20-6977192; E-mail:

m.p.peppelenbosch@amc.uva.nl
Histamine controls a large number of physiological functions by stimulating specific receptors on target cells. On the basis of their sensitivity to specific antagonists and agonists, three types of receptors for histamine have been characterized and named: the histamine receptor $\mathrm{H}_{1}, \mathrm{H}_{2}$, and $\mathrm{H}_{3}$ (3). In general, activation of the $\mathrm{H}_{3}$ receptor is associated with autoinhibition of histamine production and release, stimulation of the $\mathrm{H}_{2}$ receptor is associated with gastric acid release, and the $\mathrm{H}_{1}$ receptor is implicated in inflammation, mediating, for 
instance, bronchial constriction, vascular permeabilization, and synthesis of other inflammatory agents (4).

Exaggerated cellular histamine reactivity is associated with a variety of pathological conditions, in particular, asthmatic disease and other allergic disorders (5). The molecular details underlying the enhanced histamine reactivity remain obscure (6). Cells isolated from histamine hyperresponsive patients do not display exaggerated histamine responses ex vivo, and therefore factors present in the patient probably mediate hyperresponsiveness. Several possible mediators for histamine hyperreactivity have been described, including the cysteinyl leukotrienes $(7,8)$. In 1983 Griffin (9) suggested that these inflammatory mediators are capable of inducing enhanced histamine reactivity. In agreement with this notion, it was demonstrated shortly afterward that cysteinyl leukotrienes cause fast and transient histamine hypersensitivity in guinea pig tracheal smooth muscle and airways $(10,11)$ and that inhalation challenge with cysteinyl leukotrienes produces hyperreactivity to histamine in human subjects $(12,13)$. Furthermore, we recently demonstrated that in F9 embryonic carcinoma cells, histamine responses are strongly enhanced by prior application of leukotriene $\mathrm{D}_{4}\left(\mathrm{LTD}_{4}\right)$ or leukotriene $\mathrm{E}_{4}\left(\mathrm{LTE}_{4}\right)(6)$. Therefore, cysteinyl leukotrienes appear to be capable of increasing histamine responsiveness both in vitro and in vivo, and in vitro stimulation of cells with these inflammatory lipids might provide a model system for studying histamine hyperreactivity.

These considerations prompted us to test the effect of cysteinyl leukotrienes on histamine responses of cells associated with histamine reactivity in vivo. Here we report that $\mathrm{LTD}_{4}$ and $\mathrm{LTE}_{4}$ enhance histamine-induced prostaglandin $E_{2}$ $\left(\mathrm{PGE}_{2}\right)$ production in immortalized mouse macrophages as well as in primary isolated human monocytes and human umbilical smooth muscle cells. This increase in histamine responsiveness coincided with an immediate and transient appearance of additional $\mathrm{H}_{1}$ receptors on the plasma membrane as determined by Scatchard analysis. We conclude that stimulation of histamine responses by cysteinyl leukotrienes is a general phenomenon in cell types mediating histamine hyperreactivity in pathophysiology, and that this effect is probably mediated by a recruitment of additional $\mathrm{H}_{1}$ receptors to the plasma membrane.

\section{Materials and Methods}

Chemicals

Histamine dihydrochloride, serotonin, pyrilamine (maleate salt), and lipopolysacharide (LPS) from E. coli serotype 0111:B4 were obtained from Sigma (St. Louis, MO). Leukotrienes were from Cayman Chemical (Ann Arbor, MI), fetal calf serum (FCS) and DMEM/F12 medium were from Gibco BRL (Gaithersburg, MD), RPMI 1640 medium was from Biowhittaker (Walkersville, $\mathrm{MD}$ ), and the prostaglandin $\mathrm{E}_{2}$ biotrak EIA system and [pyridinyl- $-{ }^{3} \mathrm{H}$ ] pyrilamine were obtained from Amersham Life Science (Buckinghamshire, UK). Tumor necrosis factor $\alpha$ (TNF- $\alpha$ ) and the murine macrophage 4/4 clone, isolated as described previously (14), were a kind gift from Professor Van Roy from the Department of Molecular Biology, University of Ghent.

\section{Cell Culture}

For routine culture, murine macrophages were grown in RPMI 1640 medium supplemented with $7.5 \%$ FCS, $2 \mathrm{mM}$ L-glutamine, $100 \mathrm{U} / \mathrm{ml}$ penicillin, $0.1 \mathrm{mg} / \mathrm{ml}$ streptomycin, and $40 \mu \mathrm{M}$ $\beta$-mercaptoethanol (complete RPMI). The primary culture of human smooth muscle cells was grown in Dulbecco's modified Eagle's medium (DMEM) supplemented with $7.5 \%$ FCS, $2 \mathrm{mM}$ L-glutamine, $100 \mathrm{U} / \mathrm{ml}$ penicillin, and $0.1 \mathrm{mg} / \mathrm{ml}$ streptomycin on gelatine-coated culture dishes. All incubations were carried out at $37^{\circ} \mathrm{C}$ under a humidified atmosphere of $95 \%$ air $/ 5 \% \mathrm{CO}_{2}$. The cells were passaged two times a week using EDTA $(0.2 \mathrm{mg} / \mathrm{ml})$ for the macrophages and trypsine $(0.05 \%)$-EDTA $(0.2 \mathrm{mg} / \mathrm{ml})$ for the smooth muscle cells. The cells were plated on 24-well dishes 2 days before experimentation.

\section{Isolation of Human Blood Monocytes}

Blood was taken from six healthy volunteers and diluted 1:2 (v/v) with phosphate-buffered saline (PBS) solution. Peripheral blood mononuclear cells (PBMC) were isolated by centrifugation of diluted blood on a Ficoll gradient $(1400 \times \mathrm{g}, 20$ $\min , 20^{\circ} \mathrm{C}$ ). PBMC were washed twice with complete RPMI 1640 medium by centrifugation $\left(600 \times \mathrm{g}, 10 \mathrm{~min}, 20^{\circ} \mathrm{C}\right)$. Human monocytes were isolated by plating PBMC in 24-well dishes $\left(2 \times 10^{5}\right.$ cells/well $)$. Following a 2 -hr attachment period, the medium was removed by aspiration; monolayers were rinsed twice with fresh complete RPMI 1640 medium. Human monocytes 
were used for $\mathrm{PGE}_{2}$ determinations and for Scatchard analysis the next day.

\section{$P G E_{2}$ Determinations}

For $\mathrm{PGE}_{2}$ determinations cells were maintained in serum-free medium for $3 \mathrm{hr}$ and challenged with different stimuli, such as different concentrations of histamine, $100 \mathrm{ng} / \mathrm{ml} \mathrm{LTD}_{4}$ or $\mathrm{LTE}_{4}$, $5 \%$ FCS, $50 \mathrm{ng} / \mathrm{ml}$ TNF- $\alpha, 10 \mu \mathrm{g} / \mathrm{ml}$ LPS, and 10 $\mu \mathrm{M}$ acetylcholine for $\mathrm{l} \mathrm{hr}$. Subsequently, the supernatant of the cells was collected and prostaglandin $\mathrm{E}_{2}$ production was measured using a commercially available immunoassay (Amersham Life Science) according to the manufacturer's protocol.

\section{$I^{3}$ H]-Pyrilamine Binding}

Scatchard analysis was performed on intact cells as described earlier. For Scatchard analysis, cells were serum starved for $1 \mathrm{hr}$ and where appropriate, stimulated with $100 \mathrm{ng} / \mathrm{ml} \mathrm{LTD}_{4}$ or $\mathrm{LTE}_{4}$, $10 \%$ FCS, $1 \mu \mathrm{M}$ serotonin, $10 \mu \mathrm{M}$ acetylcholine, and $2 \mu \mathrm{M}$ bradykinin for different time intervals at $37^{\circ} \mathrm{C}$. Subsequently, cells were labeled for 75 min at $4^{\circ} \mathrm{C}$ in PBS containing $\left.4 \mathrm{nM} \mathrm{[}{ }^{3} \mathrm{H}\right]$-pyrilamine and 12 different concentrations of unlabeled pyrilamine. The reaction was stopped by washing the cells six times with ice-cold PBS and cells were lysed with $1 \%$ NP40 for at least 30 min. The bound radioactivity was determined by liquid scintillation counting. In each experiment each condition was performed in duplicate.

In general, Scatchard plots made in intact cells show considerable nonspecific low-affinity binding of $\left[{ }^{3} \mathrm{H}\right]$-pyrilamine. Therefore, Scatchard plots were fitted according to a one- or two-site model, using the following formula:

$$
\begin{aligned}
\text { Bound } / \text { Free }= & 0.5\left\{\left[\mathrm{~B}_{\max 1}-\text { Bound }\right] / \mathrm{K}_{\mathrm{d} 1}\right. \\
& \left.+\left[\mathrm{B}_{\max 2}-\text { Bound }\right] / \mathrm{K}_{\mathrm{d} 2}\right\} \\
& +0.5 \sqrt{ }\left\{\left[\left(\mathrm{B}_{\max 1}-\mathrm{Bound}\right) / \mathrm{K}_{\mathrm{d} 1}\right.\right. \\
& \left.+\left(\mathrm{B}_{\max 2}-\text { Bound }\right) / \mathrm{K}_{\mathrm{d} 2}\right]^{2} \\
& \left.\left.\quad+4\left(\mathrm{~B}_{\max 1} \mathrm{~B}_{\max 2}\right) /\left(\mathrm{K}_{\mathrm{d} 1} \mathrm{~K}_{\mathrm{d} 2}\right)\right]\right\}
\end{aligned}
$$

in which $B_{\max 1}, B_{\max 2}, K_{d 1}$, and $K_{d 2}$ are the respective maximal binding capacities and dissociation constants of the different affinities. The observed points of the Scatchard plots of unstimulated cells were satisfactory fit with a onesite (low-affinity) model, while two affinity binding sites could be distinguished in the sensitized cells. To determine the best fit, we calculated the $\chi^{2}$ distribution of the estimated curve relative to the observed values. We accepted the fit if the $\chi^{2}$ did not exceed the $p$ value of $5 \%$.

\section{Results}

Leukotrienes Induce Histamine Hyperresponsiveness In Vitro

The molecular mechanisms underlying histamine hyperresponsiveness are still poorly understood, partly as a consequence of the absence of an in vitro system for studying this process. Leukotrienes are capable of inducing histamine hypersensitivity in vivo. Recently, we showed that these inflammatory compounds augment histamine responses in certain embryo carcinoma cell lines (6). We decided, therefore, to test the effect of cysteinyl leukotrienes on cell types associated with histamine reactivity in vivo. For assaying histamine responses, we used the histamine-induced production of the inflammatory lipid $\mathrm{PGE}_{2}$ as a functional measure (15). It appeared that histamine caused a small, but statistically significant, increase in $\mathrm{PGE}_{2}$ production in primary isolated human umbilical smooth muscle cells (Fig. 1A), immortalized 4/4 murine macrophages (Fig. 1B), and freshly isolated human monocytes (Fig. 1C). In the latter cell type, however, high histamine concentrations were not as effective as lower concentrations in stimulating $\mathrm{PGE}_{2}$ production. Addition of $100 \mathrm{ng} / \mathrm{ml} \mathrm{LTD}_{4}$ or $\mathrm{LTE}_{4}$ to these cell types was also capable of inducing a modest, but statistically significant, stimulation of $\mathrm{PGE}_{2}$ synthesis highly comparable to that observed with histamine. Addition of either $\mathrm{LTD}_{4}$ or $\mathrm{LTE}_{4}$ together with histamine, however, strongly enhanced prostaglandin $\mathrm{E}_{2}$ release in both smooth muscle cells and macrophages, as well as monocytes (Fig. 1A-C). We concluded that cysteinyl leukotrienes are capable of increasing histamine responsiveness in vitro in cell types relevant for histamine hypersensitivity in vivo.

\section{Histamine Hyperresponsiveness Induced by Fetal Calf Serum}

To further characterize the induction of histamine responsiveness, we investigated whether the histamine hyperresponsiveness was restricted to leukotrienes or can be mediated by a broader spectrum of inflammatory stimuli. We stimulated human smooth muscle cells and murine 4/4 macrophages with a variety of inflammatory stimuli, including $50 \mathrm{ng} / \mathrm{ml}$ TNF- $\alpha, 10$ 

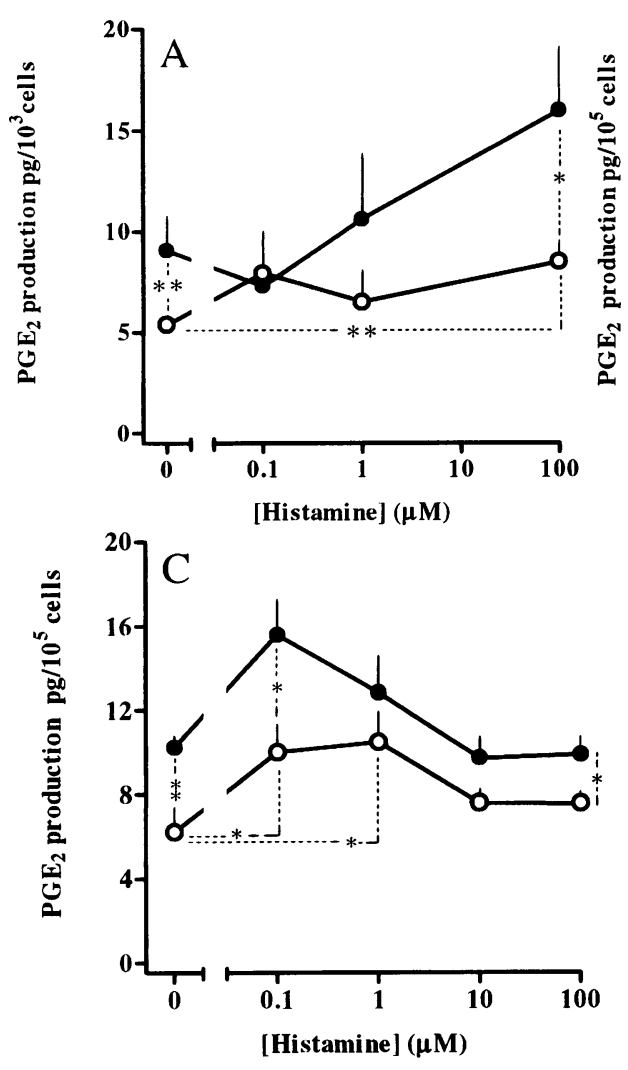

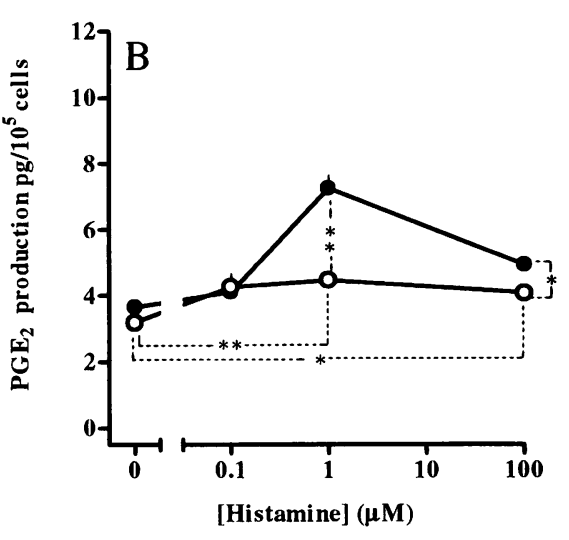

Fig. 1. Effects of cysteinyl leukotrienes on histamine hyperresponsivity in human umbilical smooth muscle cells $(A)$, immortalized 4/4 murine macrophages (B), and freshly isolated human monocytes (C). Cells were stimulated with different concentrations of histamine in the absence (open circles) or presence (filled circles) of $100 \mathrm{ng} / \mathrm{ml}$ $\mathrm{LTD}_{4}(\mathrm{~A})$ or $100 \mathrm{ng} / \mathrm{ml} \mathrm{LTE}$ $(\mathrm{B}, \mathrm{C})$ for $\mathrm{l} \mathrm{hr}$. The histamineinduced $\mathrm{PGE}_{2}$ production was used as a functional measure to determine the histamine responses in these cells. Results represent the mean and standard error of four independent experiments. Statistically significant differences were calculated using the $t$ test; ${ }^{*} p<0.05$ and ${ }^{* *} p<0.01$. $\mu \mathrm{g} / \mathrm{ml}$ LPS, and $10 \mu \mathrm{M}$ acetylcholine and $5 \%$ FCS, in the presence or absence of histamine. Neither TNF- $\alpha$, LPS, nor acetylcholine enhanced histamine-induced $\mathrm{PGE}_{2}$ synthesis (data not shown). In contrast, FCS was capable of stimulating histamine-induced $\mathrm{PGE}_{2}$ production in smooth muscle cells (Fig. 2). Although application of FCS alone induced increased $\mathrm{PGE}_{2}$ release compared to unstimulated cells, co-application of histamine and FCS had a strong synergistic effect (Fig. 2). Apparently, induction of enhanced histamine responsiveness is not a general consequence of inflammatory stimulation but a specific reaction to a subset of different stimuli.

\section{Leukotrienes Cause an Immediate Appearance of Additional $\mathrm{H}_{1}$ Receptors on the Plasma Membrane}

Induction of increased histamine responses in vitro seems to be associated with an upward shift of the histamine dose-response curve, instead of a shift to the left (Fig. 1). This suggests that induction of histamine responses involves either an appearance of more histamine receptors on the plasma membrane or a more efficient signaling per receptor and not an increase in receptor affinity. We decided to test the effect of leukotrienes in Scatchard analysis, which allows deter-

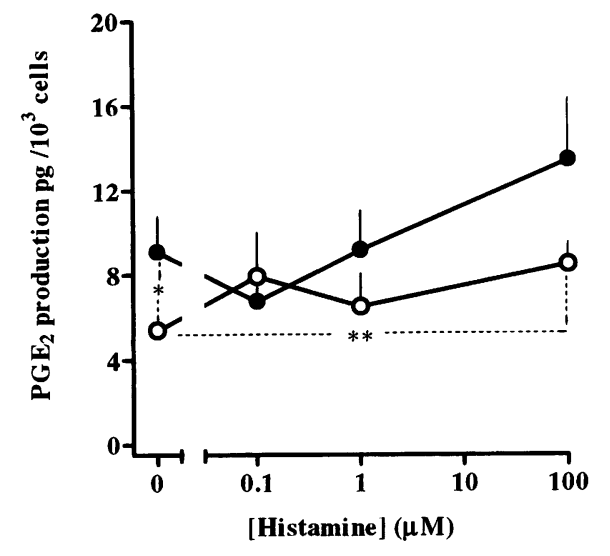

Fig. 2. Effects of FCS on histamine hyperresponsivity in human umbilical smooth muscle cells. Cells were stimulated with different concentrations of histamine in the absence (open circles) or presence (filled circles) of $5 \%$ FCS for $1 \mathrm{hr}$. The histamine-induced $\mathrm{PGE}_{2}$ production was used as a functional measure to determine the histamine responses in these cells. Results represent the mean and standard error of three independent experiments. Statistically significant differences were calculated using the $t$-test; ${ }^{* *} p<0.01$.

mination of both histamine receptor affinity as well as the receptor number. Unfortunately, we were not able to culture primary isolated umbil- 
Table 1. Effects of leukotriene $E_{4}$ on number of histamine $\mathrm{H}_{1}$ receptors in human peripheral blood monocytes

\begin{tabular}{lccc}
\hline Volunteer & $\begin{array}{c}\text { Receptors/ } \\
\text { cell before } \\
\text { stimulation }\end{array}$ & $\begin{array}{c}\text { Receptors/ } \\
\text { cell after } \\
\text { stimulation }\end{array}$ & $\begin{array}{c}\mathbf{K}_{\mathbf{d}} \\
(\mathbf{n M})\end{array}$ \\
\hline A & 54207 & 105403 & 6 \\
B & 45173 & 90345 & 6 \\
C & 22586 & 48184 & 5.5 \\
D & 12046 & 57219 & 6.7 \\
E & 2259 & 9787 & 3 \\
\end{tabular}

Blood was isolated from five healthy volunteers (A-E) and monocytes were prepared. These cells were stimulated with leukotriene $\mathrm{E}_{4}(100 \mathrm{ng} / \mathrm{ml})$ for $15 \mathrm{~min}$. Scatchard analysis was performed to determine number of receptors per cell as described in Materials and Methods.

ical smooth muscle cells in sufficient amounts to allow Scatchard analysis, but in both murine macrophages as well as primary isolated human monocytes histamine receptors are readily detected. Using $\left[{ }^{3} \mathrm{H}\right]$-mepyramine as a probe (which has an approximately 1000-fold higher affinity for the histamine $\mathrm{H}_{1}$ receptor than histamine itself), we observed in these cells histamine receptors exhibiting an apparent $K_{d}$ value of 3-6 $\mathrm{nM}$ for mepyramine, which is well in line with the reported values of this receptor (6) (Table 1, Figs. 3 and 4). $\mathrm{LTE}_{4}$ stimulation did not affect the affinity of these histamine $\mathrm{H}_{1}$ receptors, but strongly enhanced the number of histamine receptors in both human monocytes isolated from five different healthy volunteers as well as in $4 / 4$ mouse macrophages. This effect was specific to cysteinyl leukotrienes: using Scatchard analysis we tested the effect of adding different inflammatory stimuli to macrophages on histamine receptor number, including $\mathrm{LTD}_{4}$, bradykinin, acetylcholine, and serotonin, and only $\mathrm{LTD}_{4}$ mimicked the effect of $\mathrm{LTE}_{4}$ (not shown). We propose, therefore, that a leukotriene-dependent increase in receptor number underlies the leukotriene-induced increase in $\mathrm{PGE}_{2}$ production.

\section{Temporal Kinetics of Histamine Receptor Induction}

To further characterize the leukotriene-induced increase in histamine receptors, we investigated the time-dependency of this effect. As depicted in Figures 5 and 6, in both murine macrophages

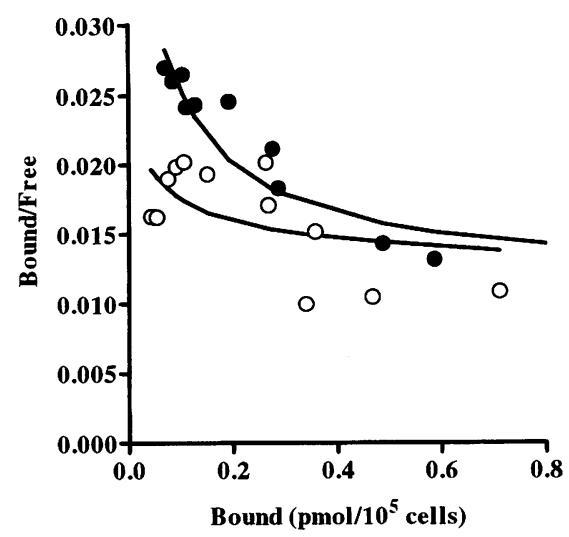

Fig. 3. Effects of leukotriene $E_{4}$ on number of histamine $\mathrm{H}_{1}$ receptors in murine macrophages. The Scatchard plot represents the binding of $\left[{ }^{3} \mathrm{H}\right]$-pyrilamine to murine macrophages, left unstimulated (open circles) or stimulated (filled circles) with $\mathrm{LTE}_{4}(100 \mathrm{ng} / \mathrm{ml})$ for $10 \mathrm{~min}$. Scatchard analysis was performed to determine number of receptors per cell as described in Materials and Methods. We measured $1.9 \times 10^{5}$ receptors/cell before stimulation and $4 \times 10^{5}$ receptors/cell after stimulation with a $\mathrm{K}_{\mathrm{d}}$ value of $5.5 \mathrm{nM}$.

as well as primary isolated human monocytes, a 5-min incubation with $\mathrm{LTE}_{4}$ already produces a strong increase in histamine receptor number. In mouse macrophages, at later time points even more histamine receptors were detected, a maximum effect being reached at $15 \mathrm{~min}$, after which receptor numbers declined again, although an increase above the control level was still detected $1 \mathrm{hr}$ post-stimulation (Fig. 5). In human monocytes, maximal induction of histamine receptors was observed $5 \mathrm{~min}$ after application of $\mathrm{LTE}_{4}$ whereas at later time points, the number of receptors gradually declined (Fig. 6). These results demonstrate, therefore, that the cysteinyl leukotriene-induced increase in histamine $\mathrm{H}_{1}$ receptor number is extremely fast, and of a transient nature.

\section{Discussion}

Histamine reactivity is under dynamic control and exaggerated histamine responses have been implicated in a variety of pathological conditions. The molecular mechanisms regulating histamine responsiveness are poorly understood. Strikingly, cells isolated from patients exhibiting clinical histamine hyperreactivity do not display such histamine hyperreactivity in vitro (16-19), demonstrating that factors present in the patient 

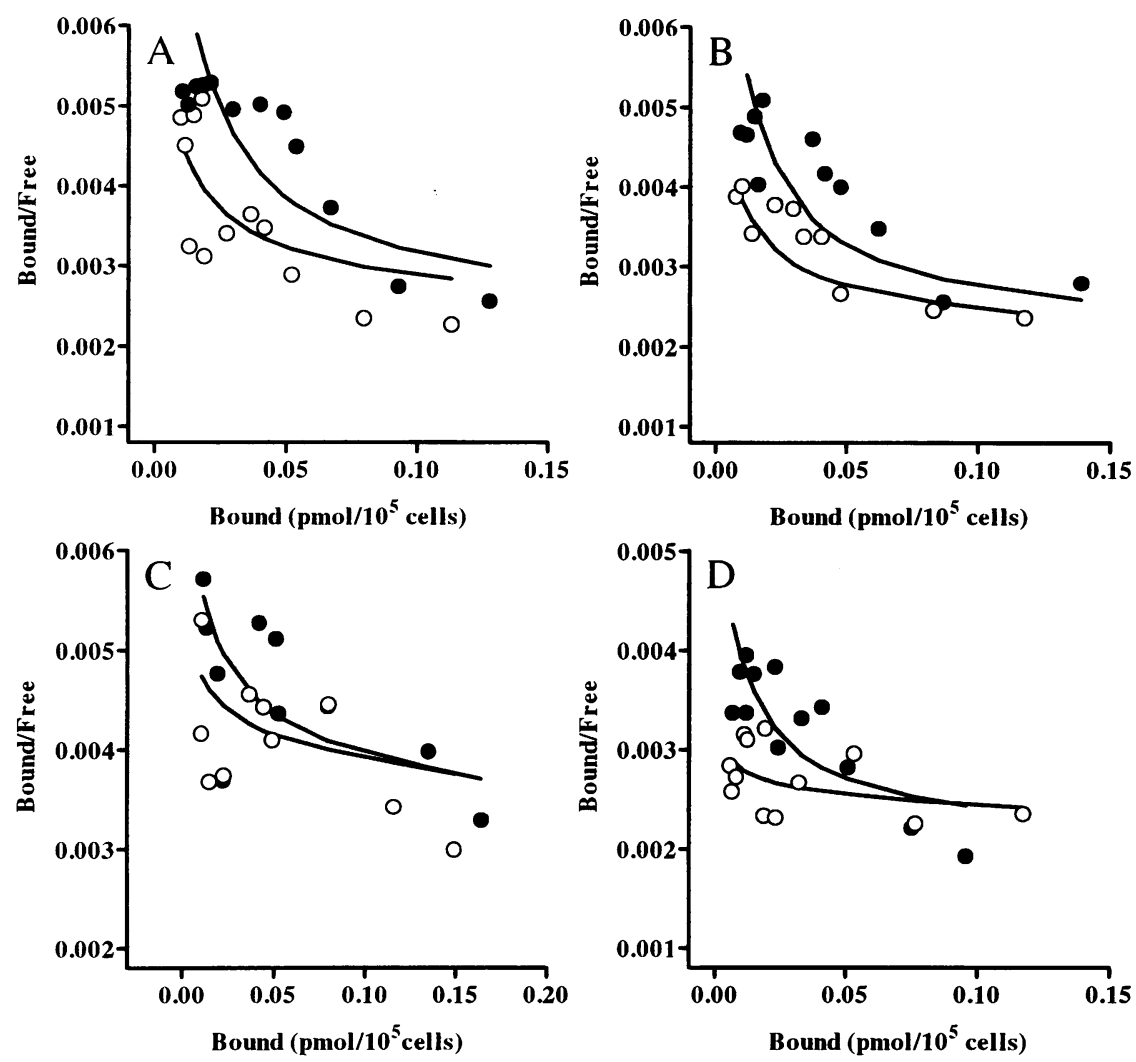

Fig. 4. Effects of leukotriene $E_{4}$ on number of histamine $H_{1}$ receptors in human peripheral blood monocytes. Blood was isolated from four healthy volunteers (A-D) and monocytes were prepared. The following day, monocytes were either left unstimulated (open circles) or stimulated with leukotriene $\mathrm{E}_{4}(100 \mathrm{ng} / \mathrm{ml})$ (filled circles) for $15 \mathrm{~min}$. Scatchard analysis was performed to determine number of receptors per cell as described in Materials and Methods.

are essential for histamine hyperresponsiveness. These factors have not yet been conclusively identified, but may include cysteinyl leukotrienes, as these inflammatory lipids enhance histamine reactivity in human subjects in vivo $(9,12,13,20,21)$. Recently, we demonstrated that such cysteinyl leukotrienes enhance histamine responses in certain embryo carcinoma cell lines (6). We decided to investigate, therefore, whether cysteinyl leukotrienes are able to increase histamine responses in cell types important in histamine reactivity in vivo. We observed that in vitro stimulation with these inflammatory lipids strongly enhanced the cellular reaction to histamine in primary isolated umbilical smooth muscle cells, in a murine macrophage cell line, and in human monocytes. Therefore, cysteinyl leukotrienes are direct regulators of histamine responsivity ex vivo.

Our experimental system allowed us to investigate the mechanisms underlying histamine hyperresponsiveness in vitro. We employed $\mathrm{PGE}_{2}$ production as a measure for histamine responses, which was determined $\mathrm{l}$ hr after stimulation. This time frame indicates that induction of enhanced histamine responsiveness by cysteinyl leukotrienes is protein synthesis indepen-

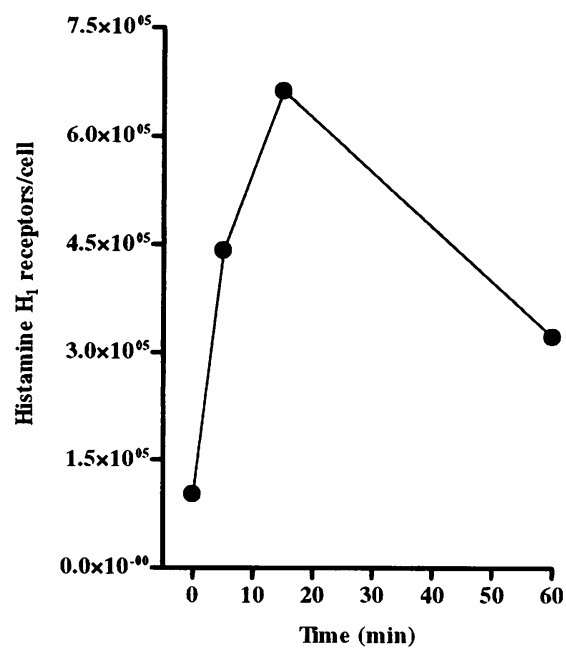

Fig. 5. Transient nature of histamine receptor induction in murine macrophages. Macrophages were stimulated with $\mathrm{LTE}_{4}$ for different time intervals and Scatchard analysis was performed to determine number of receptors per cell as described in Materials and Methods.

dent, in agreement with in vivo results (12). This leaves three different possibilities of explaining the induction of increased histamine responses: 

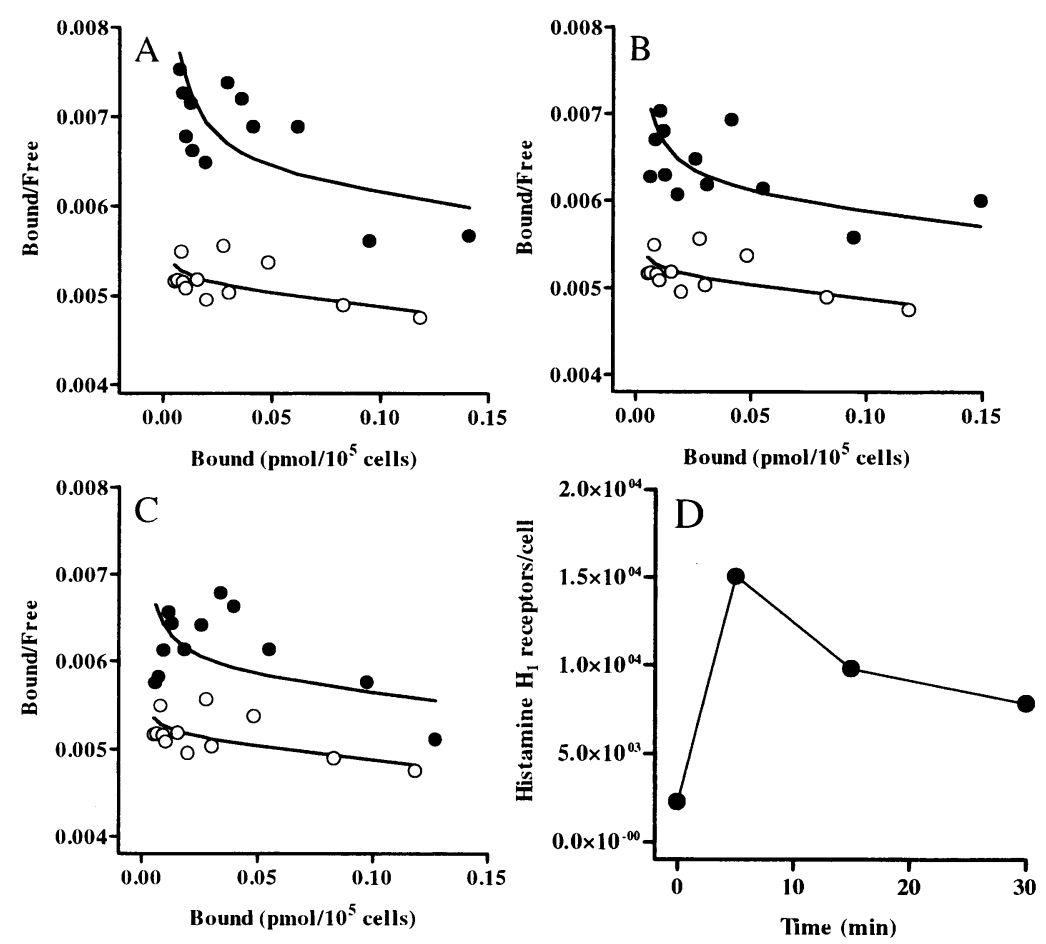

Fig. 6. Transient nature of histamine receptor induction in human blood monocytes. Blood was taken from one volunteer ( $E$ in Table 1) and monocytes were isolated. The following day, the cells were either left unstimulated (open circles) or stimulated with $\mathrm{LTE}_{4}(100 \mathrm{ng} / \mathrm{ml})$ for $5 \mathrm{~min}(\mathrm{~A}), 15$ min (B) or 30 min (C) (filled circles). (D) Amount of histamine $\mathrm{H}_{1}$ receptors at the indicated time intervals. Scatchard analysis was performed to determine number of receptors per cell as described in Materials and Methods.

first, cysteinyl leukotrienes may increase the affinity of the histamine receptor for its ligand, second, leukotrienes may induce increased signal transduction per receptor, and third, leukotrienes may unmask histamine receptors already present but unable to interact with their ligands. The dose-response relationship of the histamineinduced prostaglandin synthesis does not display a leftward shift on Scatchard analysis after stimulation with cysteinyl leukotrienes, which is apparently in disagreement with a leukotriene-induced increase in histamine receptor affinity. Scatchard analysis did not reveal differences in histamine receptor affinity before or after stimulation of histamine responsiveness, but it did show an increase in receptor number after addition of leukotrienes to either primary isolated monocytes or mouse macrophages; this increase appears to correlate with enhanced histamineinduced prostaglandin production. We propose, therefore, that cysteinyl leukotrienes may induce histamine hyperreactivity in vitro by unmasking histamine receptors that were previously unable to bind their ligand.

The molecular details by which cysteinyl leukotrienes may produce such an unmasking of histamine receptors remain unclear. In general, receptors may be continuously recycled between the plasma membrane and the endosomes. Therefore, a pool of histamine receptors may exist that is physically unable to bind its ligand, due to an endosomal localization. As it is now becoming clear that many external stimuli may profoundly influence vesicular trafficking, it is conceivable that cysteinyl leukotrienes mobilize such an endosomal pool of histamine receptors to produce an increased number of receptors on the plasma membrane and enhanced histamine responsiveness. Alternatively, a pool of histamine receptors unable to bind their ligand may exist on the plasma membrane. Addition of leukotriene may induce a conformational change in these histamine receptors already present on the plasma membrane, to allow ligand binding. Obviously, further experimental work is required to discern between these possibilities.

A dynamic regulation of histamine responsiveness is further supported by the transient nature of the effects observed. Both in macrophages and primary isolated human monocytes, maximal numbers of histamine receptors are observed within 5-15 min after stimulation with cysteinyl leukotrienes, and clearly decline again within an hour. This corresponds well with the timing of kinetics of the leukotriene-induced histamine hyperreactivity in guinea pig tracheal smooth muscle observed by Lee et al. (10), who observed maximal stimulation of histamine-induced contraction 10 to $15 \mathrm{~min}$ after application of cysteinyl leukotriene and a return to unstimu- 
lated histamine responsiveness within $30 \mathrm{~min}$. Studies performed in vivo, however, have shown much longer durations of cysteinyl leukotriene histamine hyperresponsiveness (13), therefore, the effects observed in the present study cannot be directly extrapolated to the asthmatic patient. As histamine receptor activation is in itself a potent inducer of leukotriene synthesis, positive feedback may partly explain the discrepancy between the effects observed in vitro and in vivo. Furthermore, in vivo production of other secondary mediators (cytokines, interleukins, etc.) clearly influences histamine hyperreactivity (15). Therefore, studies investigating cysteinyl leukotriene-induced histamine receptor unmasking in cells obtained in patients suffering from histamine hypersensitivity are needed to establish whether the enhancement of histamine receptor numbers observed in vitro may also be relevant in pathophysiology. Studies addressing this problem are currently in progress.

\section{Acknowledgments}

The authors thank our volunteers for their cooperation and the other members of our laboratories for stimulating discussions.

\section{References}

1. Werle E, Lorenz W. (1966) Histamine and histidine decarboxylases in the thyroid and the thymus. Biochem. Pharmacol. 15: 1059-1070.

2. Kahlson G, Rosengren E. (1968) New approaches to the physiology of histamine. Physiol. Rev. 48: 155-196.

3. Hill SJ, Ganellin CR, Timmerman H, et al. (1997) Classification of histamine receptors. Pharmacol. Rev. 49: 253-278.

4. Hill SJ. (1990) Distribution properties and functional characteristics of three classes of histamine receptors. Pharmacol. Rev. 42: 45-83.

5. Barnes PJ, Chung KF, Page CP. (1998) Inflammatory mediators of asthma: an update. Pharmacol. Rev. 50: 515-596.

6. Bloemers SM, Verheule S, Peppelenbosch MP, Smit MJ, Tertoolen LG, de Laat S. (1998) Sensitisation of the histamine $\mathrm{Hl}$ receptor by increased ligand affinity. J. Biol. Chem. 273: 2249-2255.

7. Busse WW. (1998) Leukotrienes and inflammation. Am. J. Respir. Crit. Care Med. 157: S210-S213.

8. Thien FC, Walters EH. (1995) Eicosanoids and asthma: an update. Prostaglandins Leukot Essent Fatty Acids 52: 271-288.

9. Griffin M, Weiss JW, Leitch AG, et al. (1983) Effects of leukotriene D on the airways of asthma. N. Engl. J. Med. 308: 436-439.
10. Lee TH, Austen KF, Corey EJ, Drazen JM. (1984) Leukotriene E4-induced airway hyperresponsiveness of guinea pig tracheal smooth muscle to histamine and evidence for three separate sulfidopeptide leukotriene receptors. Proc. Natl. Acad. Sci. U.S.A. 81: 4922-4925.

11. Kurosawa M, Tsukagoshi H. (1993) Inhibitory effect of a thromboxane A2 synthetase inhibitor OKY-046 on bronchial hyperresponsiveness to histamine, but not on airway wall thickening, induced by intravenous administration of leukotriene C4 in guinea-pigs. Pulm. Pharmacol. 6: 247253.

12. Arm JP, Spur BW, Lee TH. (1988) The effects of inhaled leukotriene $\mathrm{E} 4$ on the airway responsiveness to histamine in subjects with asthma and normal subjects. J. Allergy Clin. Immunol. 82: 654660.

13. O'Hickey SP, Hawksworth RJ, Fong CY, Arm JP, Spur BW, Lee TH. (1991) Leukotrienes C4, D4 and E4 enhance histamine responsiveness in asthmatic airways. Am. Rev. Respir. Dis. 144: 10531057.

14. Desmedt $M$, Rottiers $P$, Dooms H, Fiers W, Grooten J. (1998) Macrophages induce cellular immunity by activating Thl cell responses and suppressing Th2 cell responses. J. Immunol. 160: 5300-5308.

15. Barnes PJ (1991) Biochemistry of asthma. Trends Biochem. Sci. 16: 365-369.

16. Fukushima C, Shimoda T, Matsuse H, et al. (1999) In vitro responses to antigen stimulation: comparison between human lung parenchyma resected from asthmatic patients and non-asthmatic patients. Ann. Allergy Asthma Immunol. 82: 179-184.

17. Bjorck T, Gustafsson LE, Dahlen SE. (1992) Isolated bronchi from asthmatics are hyperresponsive to adenosine, which apperently acts indirectly by liberation of leukotrienes and histamine. Am. Rev. Respir. Dis. 145: 1087-1091.

18. Meurs H, Koeter GH, Kauffman HF, Timmermans A, Folkers B, de Vries K. (1985) Reduced adenylate cyclase responsiveness to histamine in lymphocyte membranes of allergic asthmatic patients after allergen challenge. Int. Arch. Allergy Appl. Immunol. 76: 256-260.

19. Goldie RG, Spina D, Henry PJ, Lulich KM, Paterson JW (1986) In vitro responsiveness of human asthmatic bronchus to carbachol, histamine, betaadrenoceptor agonists and theophylline. Br. J. Clin. Pharmacol. 22: 669-676.

20. Kern R, Smith LJ, Patterson R, Krell RD, Bernstein PR. (1986) Characterization of the airway response to inhaled leukotriene D4 in normal subjects. Am. Rev. Respir. Dis. 133: 1127-1132.

21. Kaye MG, Smith LJ. (1990) Effects of inhaled leukotriene D4 and plated-activating factor on airway reactivity in normal subjects. Am. Rev. Respir. Dis. 141: 993-997. 